\title{
Service Quality of Public Terminal Users in UPT-LLAJ East Java
}

\author{
Sukesi \\ University of Dr.Soetomo, Surabaya, Indonesia \\ Rahma S. Muliasari \\ University of Airlangga, Surabaya, Indonesia
}

\begin{abstract}
A bus terminal is a public transportation infrastructure that is designated for the arrival or departure of passengers and the loading or dropping off of goods, Morlok (2005). From January $1^{\text {st }}, 2017$, the management of a Btype terminal for Inter-City Bus Transportation (AKDP) began to be handled by the Provincial Traffic and Land Transportation (LLAJ). Proportional random sampling was used to select 107 Larangan terminal users and 106 Bunder terminal users. 9 variables and 29 indicators of the qualitative descriptive method used showed that the service quality of Larangan terminal is GOOD with the highest score of bus terminal staff behavior variable (V7) are the indicators of staff attention and reliability of the staffs. The service quality of Bunder terminal is also GOOD with the highest score of the variable of bus terminal staff behavior (V7) are the indicators of hospitality and friendliness. It is recommended to optimize the utilization of the waiting room facilities as well as do the renovation of the terminal facilities to provide safety and convenience for the terminal users.
\end{abstract}

Keywords: service quality, terminal, satisfaction, East Java.

\section{INTRODUCTION}

Law of the Republic of Indonesia No. 25 of 2009 on Public Service and Change of Authority of Transportation Affairs to the Traffic and Land Transportation (LLAJ) as stipulated in Law No. 23 of 2014 on Regional Government, stating that by December $31^{\mathrm{st}}$, 2016 the latest, the authority to manage a Btype terminal for Inter-City Bus Transportation (AKDP) which was previously handled by the municipal government shall be handled by the provincial government.

A Technical Implementation Unit (UPT)-LLAJ East Java which includes Larangan terminal in Sidoarjo city and Bunder terminal in Gresik city is one of the examples of the terminal management authority delegated to East Java provincial government from 13 existing UPT-LLAJs. According to Morlok (2005), a bus terminal is a public transportation infrastructure that is designated for the arrival or departure of passengers and the loading or dropping off of goods. While Joewono \& Kubota (2006) studied about public transportation safety, the need for service improvement, and the transportation management in a terminal. Sulistyono et al. (2017) conveyed that there was an overlapping of routes in
Jember city and the lack of supervision resulted in violations of public transportation operations.

Based on the above description, it is necessary to further examine the service quality in the terminal towards the terminal users' satisfaction and what service variables are needed to satisfy the users of UPT-LLAJ East Java

\section{LITERATURE REVIEW}

\subsection{Gorvernment policy}

According to the Minister of Transportation Regulation No. 132 of 2015 on the management of land transportation terminal, a B-type terminal is a terminal whose main role is to serve public for InterCity Bus Transportation (AKDP) combined with urban and/or rural transportation service which includes the main, public, and supporting facilities.

\subsection{Public service}

According to the Minister of Utilization of State Apparatus Regulation (Permenpan) No. 16 of 2014 on guidelines for community satisfaction survey on the public service provider, to know the performance 
of public services, a survey of community satisfaction needs to be conducted in a periodical basis.

\section{RESEARCH METHOD}

The research approach used in this study was quantitative research, which is a research method that emphasizes on the testing of theories through measurement of research variables with numbers and data analysis with statistical procedures. The respondents of this study were 107 users of Larangan terminal and 106 users of Bunder terminal. Accidental sampling was used to take the sample.

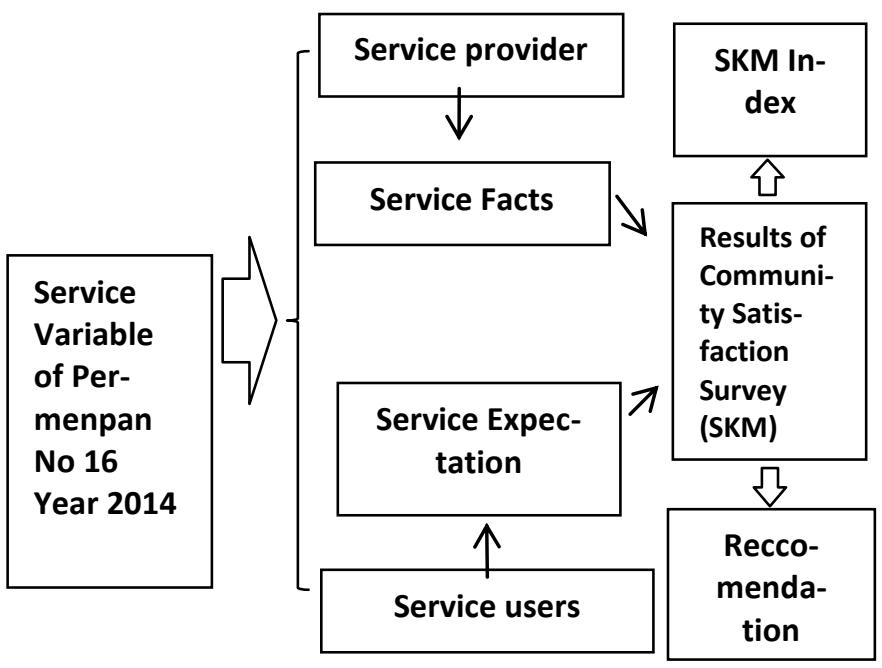

Figure 1. Framework for Preparation of Community Satisfaction Survey in UPT-LLAJ East Java.

\subsection{Instrument and activity variable}

Permenpan No. 16 of 2014 was used as a reference for the development of this research's instruments, which comprises the following 9 variables (see on Table 1).

\subsection{Data analysis technique}

$$
\begin{aligned}
& \text { Community } \\
& \begin{array}{c}
\text { Satisfaction } \\
\text { Survey }
\end{array}
\end{aligned}=\frac{\begin{array}{c}
\text { Total Value of Perception } \\
\text { Per Element }
\end{array}}{\text { Total Element Filled }} \text { X Weighted Value (1) }
$$$$
\text { Community Satisfaction Survey X } 25
$$

The interval value table is as follows (see on Table 2)
Table 1. Variables, Indicators, Service Quality of Public Transportation Service

\begin{tabular}{lll}
\hline No & Variable & Indicator \\
\hline 1 & $\begin{array}{l}\text { Service } \\
\text { Requirements } \\
\text { (V1) }\end{array}$ & $\begin{array}{l}\text { 1. Existence and condition of safety } \\
\text { of the service }\end{array}$ \\
& $\begin{array}{l}\text { 2. Existence and condition of } \\
\text { security the service }\end{array}$ \\
& $\begin{array}{l}\text { 3. Existence and condition of } \\
\text { reliability/ punctuality of } \\
\text { the service }\end{array}$ \\
& $\begin{array}{l}\text { 4. Existence and condition of } \\
\text { comfort of the service }\end{array}$ \\
& 5. Existence and condition of \\
& ease/affordability of the services \\
& 6. Existence and condition of equality
\end{tabular}
of the services

2 Service Procedure 1. Clarity of the service procedure

(V2) 2. Convenience of the service procedure

3. Suitability of the route information

3 Service Time (V3) 1. Service time

2. Punctuality of the service

3. Clarity of bus operating time information

4 Service fare (V4) 1. Suitability of the bus fare paid to the charged fare

2. Suitability of the bus fare paid to the facilities provided

5 Specification 1 . Availability of supporting facilities of Service to support bus and transport Products (V5) operational requirements

2. Availability of buses and transport according to route

6 Staff 1. Staff awareness

competencies (V6) 2. Knowledge of the staffs

7 Bus terminal 1. Staff discipline

staff behavior 2. Staff attention

(V7) 3. Reliability of the staffs

4. Hospitality and friendliness of the staffs

8 Service Standard 1. Security condition in the terminal (V8) 2. Comfort condition in terminal

3. Safety condition in the terminal

9 Complaints 1. Availability of complaint, suggestions, suggestions, and feedback feedback and handling facilities response mechanism (V9)

2. Complaints, suggestions, feedback and response mechanism

3 . Ease of complaint procedure

* source: Permenpan No 16 Year2014

Table 2. Index of Service Quality

\begin{tabular}{lllll}
\hline $\begin{array}{l}\text { Perception } \\
\text { Value }\end{array}$ & $\begin{array}{l}\text { Interval } \\
\text { value/Unit }\end{array}$ & $\begin{array}{l}\text { Interval } \\
\text { value }\end{array}$ & $\begin{array}{l}\text { Service } \\
\text { quality }\end{array}$ & $\begin{array}{l}\text { Statement } \\
\text { of service } \\
\text { Perfor- } \\
\text { mace }\end{array}$ \\
\hline 1 & $1.00-1.75$ & $25-43.75$ & D & Bad \\
2 & $1.76-2.50$ & $43.76-62.50$ & C & Fair \\
3 & $2.51-3.25$ & $62.51-81.25$ & B & $\begin{array}{l}\text { Good } \\
\text { Very } \\
4\end{array}$ \\
\hline
\end{tabular}




\section{RESULT AND DISCUSSION}

The service quality in the terminal towards the terminal users' satisfaction.

Table 3. Results of data processing of Larangan terminal users' Satisfaction

\begin{tabular}{llll}
\hline Variable & Indicator & $\begin{array}{l}\text { Average } \\
\text { value }\end{array}$ & $\begin{array}{l}\text { Level of service } \\
\text { quality }\end{array}$ \\
\hline 1 & 1 & 1.84 & C \\
& 2 & 1.93 & C \\
& 3 & 1.99 & C \\
& 4 & 1.89 & C \\
& 5 & 1.99 & C \\
2 & 6 & 1.40 & C \\
& 7 & 2.58 & B \\
3 & 8 & 3.00 & B \\
& 9 & 2.77 & B \\
& 10 & 2.58 & B \\
4 & 11 & 2.00 & C \\
& 12 & 2.48 & B \\
5 & 13 & 2.83 & B \\
& 14 & 2.52 & B \\
6 & 15 & 2.45 & B \\
& 16 & 2.50 & B \\
7 & 17 & 2.77 & B \\
& 18 & 2.79 & B \\
& 19 & 2.98 & B \\
& 20 & 2.93 & B \\
8 & 21 & 3.00 & B \\
& 22 & 3.00 & B \\
9 & 23 & 2.96 & B \\
& 24 & 2.79 & B \\
& 25 & 2.70 & B \\
& 26 & 2.30 & C \\
& 27 & 2.24 & C \\
& 28 & 3.00 & B \\
& 29 & 2.59 & B \\
\hline
\end{tabular}

source: Primary data survey 2017, processed

Table 3 shows that out of 9 variables and 29 service indicators, the result of data analysis on community satisfaction of Larangan terminal users is 62.76 meaning the service quality is classed GOOD with B-category. It signifies that most of the 107 respondents admitted that the service procedures at Larangan terminal, which include clarity, ease of access, availability of buses and transport according to route, route information, fare, competence, discipline, awareness, reliability, friendliness, and the response of the bus terminal staffs contribute to the satisfaction of Larangan terminal users.

Table 4 shows that out of 9 variables and 29 service indicators, the result of data analysis on community satisfaction of Bunder terminal users is 71.31 indicating the service quality is classed GOOD with B-category. It shows that most of the 106 respondents acknowledged that the bus terminal staffs are reliable as evidenced by their hospitality and friendliness in serving the terminal users. Another service variable that affects the terminal users' satisfaction is complaints, suggestions, feedback, and response mechanism.

Table 4. Results of data processing of Bunder Terminal users' Satisfaction

\begin{tabular}{|c|c|c|c|}
\hline Variable & Indicator & $\begin{array}{l}\text { Average } \\
\text { value }\end{array}$ & $\begin{array}{l}\text { Level of service } \\
\text { quality }\end{array}$ \\
\hline \multirow[t]{6}{*}{1} & 1 & 2.74 & B \\
\hline & 2 & 2.75 & B \\
\hline & 3 & 2.83 & B \\
\hline & 4 & 2.73 & B \\
\hline & 5 & 2.79 & B \\
\hline & 6 & 2.41 & $\mathrm{C}$ \\
\hline \multirow[t]{3}{*}{2} & 7 & 2.87 & B \\
\hline & 8 & 3.00 & B \\
\hline & 9 & 2.90 & B \\
\hline \multirow[t]{3}{*}{3} & 10 & 2.94 & B \\
\hline & 11 & 2.94 & B \\
\hline & 12 & 2.92 & B \\
\hline \multirow[t]{2}{*}{4} & 13 & 2.97 & B \\
\hline & 14 & 3.01 & B \\
\hline \multirow[t]{3}{*}{5} & 15 & 2.89 & B \\
\hline & 16 & 2.77 & B \\
\hline & 17 & 2.89 & B \\
\hline \multirow[t]{2}{*}{6} & 18 & 2.94 & B \\
\hline & 19 & 3.07 & B \\
\hline \multirow[t]{4}{*}{7} & 20 & 3.00 & B \\
\hline & 21 & 3.00 & B \\
\hline & 22 & 3.00 & B \\
\hline & 23 & 3.05 & B \\
\hline \multirow[t]{3}{*}{8} & 24 & 2.82 & B \\
\hline & 25 & 2.87 & B \\
\hline & 26 & 2.59 & B \\
\hline \multirow[t]{3}{*}{9} & 27 & 2.42 & $\mathrm{C}$ \\
\hline & 28 & 3.00 & B \\
\hline & 29 & 2.62 & B \\
\hline
\end{tabular}

source: Primary data survey 2017 , processed

What service variables are needed to satisfy the terminal users: first, the most respondents felt comfortable when in Larangan terminal, which signifies good service quality with the highest score of the variable of bus terminal staff behavior (V7) is the hospitality impression of the staffs in providing direction to the terminal users as proof of attention and reliability of the staffs to make the terminal users feel comfortable. Second, the service quality at Bunder terminal is also GOOD with the highest score of the variable of bus terminal staff behavior (V7) is the hospitality and friendliness of the staffs. The respondents both users and the bus crew felt the ease of the service procedure, such as ease of the bus fare payment. Bunder terminal staffs are caring as evidenced by the hospitality and friendliness of the staffs in helping the terminal users. 


\section{CONCLUSION AND SUGGESTIONS}

\subsection{Conclusion}

Based on the results of data analysis and discussion, it can be concluded: first is Larangan terminal and the second is Bunder terminal.

Most of the 107 respondents stated that the service was as expected, meaning the service quality was good and the average score is 2.51 in category B. The variable of bus terminal staff behavior (V7) that gave the highest score from the 9 service variables is staffs' friendliness in giving direction to terminal users as proof of attention and reliability of the staffs to make terminal users feel comfortable.

Most of the 106 respondents admitted that the service was as expected, meaning the service quality was good and the average score is 2.85 in category B. The variable of bus terminal staff behavior (V7) that gave the highest score from the 9 service variables is hospitality and friendliness. The respondents both users and the bus crew felt the ease of the service procedure, such as ease of the bus fare payment. Bunder terminal staffs are caring as evidenced by the hospitality and friendliness of the staffs in helping the terminal users.

\subsection{Suggestions}

Based on the results of the analysis, the suggestions are the followings: first, Larangan Terminal i.e. More optimal utilization of waiting room facilities for terminal users; Optimal utilization of bus arrival and departure facilities; Replacement of old buses; Provision of facilities for pregnant and lactating women; Provision of facilities for persons with disabilities; Total improvement of terminal facilities to provide convenience, safety, and comfort for terminal users/passengers.

Second is Bunder Terminal i.e. Gradual construction of facilities such as health facilities, waiting room facilities, ATM facilities, facilities for pregnant-lactating women and persons with disabilities to improve customer services to improve customer service; Construction of representative terminal office so as to provide optimal service; The buses with Bojonegoro - Lamongan - Semarang route going to Surabaya should transit in Bunder terminal (Gresik).

\section{REFERENCES}

Joewono, T.B \& Kubota, H. 2006 Safety And Security Improvement In Public Transportation Based On Public Perception In Developing Countries. IATASS Research 30(1): 86-100.

Morlok, EK. 2005. Pengantar Teknik dan Perencanaan Transportasi. Erlangga. Jakarta
Sulistyono, S. Djakfar, F. \& Wicaksono, A. 2017 Kebijakan Penataan Jaringan Trayek Angkutan Umum Perkotaan Jember. Jurnal Transportasi 17(2): 108.

Keputusan Menteri Pendayagunaan Aparatur Negara (Kepmenpan) Nomor 16 Tahun 2014 tentang Pedoman Survei Kepuasan Masyarakat Terhadap Penyelenggaraan Pelayanan Publik.

Peraturan Menteri Perhubungan Nomor PM 132 Tahun 2015 tentang Penyelenggaran Terminal Angkutan Jalan.

Undang-Undang Republik Indonesia Nomor 25 Tahun 2009 tentang Pelayanan Publik.

Undang-Undang Republik Indonesia Nomor 23 Tahun 2014 tentang Pemerintah Daerah. 